\title{
KAJIAN PEMENUHAN KEBUTUHAN OKSIGEN SKALA RUMAH \\ TANGGA SEBAGAI UPAYA PEDULI LINGKUNGAN MELALUI PEMANFAATAN AREA PEKARANGAN
}

DOI: https://doi.org/10.33024/jkpm.v4i4.4071

\section{Yanti Hermayanti ${ }^{1}$, Asih Purwandari Wahyoe Puspita², Tirta Adikusuma Suparto ${ }^{3}$}

\author{
${ }^{1}$ Fakultas Keperawatan, Universitas Padjadjaran \\ ${ }^{2-3}$ Program Studi D3 Keperawatan, Fakultas Pendidikan Olahraga dan \\ Kesehatan, Universitas Pendidikan Indonesia
}

Disubmit: 18 Maret 2021 Diterima: 07 April 2021 Diterbitkan: 03 Agustus 2021

\begin{abstract}
Email: yanti.hermayanti@unpad.ac.id, tirta.adikusuma.123@upi.edu, asihpurwandari@upi.edu
\end{abstract}

\begin{abstract}
ABSTRAK
Penghijauan di sekitar rumah adalah salah satu upaya pengelolaan lingkungan hidup yang bisa dilakukan oleh keluarga. Bila kegiatan tersebut dilakukan oleh setiap keluarga, maka salah satu kebutuhan lingkungan untuk pemenuhan kebutuhan oksigen, dapat difasilitasi dan dipenuhi bersama. Artikel ini bertujuan untuk memberikan gambaran kepada keluarga dalam memenuhi kebutuhan oksigen. Metode yang digunakan adalah deskriptif, berfokus pada penerapan suatu tindakan. Penghijauan dapat dilakukan pada area depan rumah, pada area samping dan pinggir jalan, dan pada area tanah. Pada area depan bisa ditanam berbagai macam tanaman hias dan produktif. Pada area samping dan pinggir jalan bisa dimanfaatkan untuk menanam berbagai jenis tanaman sayuran dan obat. Pada area tanah bisa di tanam jenis pohon yang lebih besar dan produktif. Penanaman berbagai macam jenis pohon di tempat terbuka dan pemilihan tanaman akan membantu dalam memenuhi kebutuhan oksigen per rumah tangga, menambah kesejukan, kelembaban, kenyamanan lingkungan. Mengingat besarnya manfaat tersebut, perlu adanya programprogram promosi penghijauan di sekitar rumah oleh Pemerintah RI, Pemerintah Provinsi, Pemerintah Kota/Kabupaten, dan organisasi terkait lainnya.
\end{abstract}

Kata Kunci: kebutuhan oksigen, rumah tangga, lingkungan, pemanfaatan area pekarangan

\begin{abstract}
Greening around the house is one of the environmental management efforts that can be done by families. If these activities are carried out by each family, then one of the environmental needs to fulfill oxygen needs can be facilitated and fulfilled together. This article aims to provide an overview for families in meeting their oxygen needs. The method used is descriptive, focusing on the implementation of an action. Greening can be done in the front area of the house, on the side and roadside areas, and on the land area. In the front area,
\end{abstract}


various kinds of ornamental and productive plants can be planted. In the side and roadside areas, it can be used to plant various types of vegetable and medicinal plants. In the land area, larger and more productive tree species can be planted. Planting various types of trees in the open and selecting plants will help meet the oxygen demand per household, add coolness, humidity, and environmental comfort. Given these benefits, it is necessary to have green promotion programs around the house by the Government of the Republic of Indonesia, the Provincial Government, Kota/Kabupaten Governments, and other related organizations.

Keywords: oxygen demand, household, environment, utilization of the yard area

\section{PENDAHULUAN}

Pemerintah pusat telah membuat berbagai aturan berkaitan dengan lingkungan hidup yang tertuang dalam Peraturan Pemerintah Republik Indonesia No. 66 Tahun 2014 untuk digunakan seluruh pemangku kepentingan menjalankannya peran dan fungsinya (Pemerintah RI, 2014). Pemerintah di Jawa Barat-pun menanggapi pentingnya aturan tersebut dengan membuat Peraturan Daerah Provinsi Jawa Barat No. 5 Tahun 2015 tentang pengelolaan jasa lingkungan hidup (Gubernur JABAR, 2015), kedua peraturan tersebut menekankan bahwa lingkungan hidup sangat penting untuk dikelola dengan baik karena akan mempengaruhi hajat hidup orang banyak.

Lingkungan yang tidak dikelola dengan baik akan berdampak buruk pada kesehatan mahluk hidup. Contoh langsung akibat polusi udara adalah iritasi saluran pernapasan yang memicu terjadinya penyakit saluran pernapasan non spesifik seperti asma, bronchitis, pneumokoniosis yang di akibatkan oleh partikel debu udara, virus, bakteri dan zat berbahaya lainnya yang mencemari udara (Budiyono, 2010). Kondisi ini mungkin akan berdampak lebih buruk karena dari 100 orang, baru $26,0 \%$ yang memiliki tingkat pengetahuan baik tentang dampak polusi udara pada kesehatan (Balan, 2019). Banyaknya penebangan pohon untuk pembangunan tata kota akan memperburuk keadaan lingkungan karena karbon meningkat dan suhu lingkungan menjadi panas (Prabaningtyas \& Priyo, 2020). Akibat dari lingkungan tercemar akan terjadi hujan asam yang secara langsung dapat mempercepat kerusakan benda yang terbuat dari besi dan pengasaman sungai dan danau disekitar lingkungan (Budiyono, 2010). Kondisi tersebut perlu dicermati karena secara langsung akan berdampak pada kondisi kesehatan dan ekonomi keluarga.

Untuk mengurangi dampak tersebut, setiap warga berkewajiban melakukan kegiatan memelihara lingkungan, agar udara tidak tercemar. Salah satu upaya yang bisa dilakukan adalah penghijauan di sekitar rumah dengan memanfaatkan halaman pekarangan, pinggir jalan dan area terbuka lainnya. Kegiatan ini akan membawa manfaat ganda, yaitu mengatasi polusi dengan membantu memenuhi kebutuhan oksigen sendiri di sekitar rumah dan memanfaatkan hasil tanam untuk kebutuhan harian. Kegiatan tersebut akan menambah area terbuka hijau yang diperlukan, oksigen akan dihasilkan lebih banyak (Manisalidis, Stavropoulou, Stavropoulos \& Bezirtzoglou, 2020).

Bila kegiatan tersebut dilakukan oleh setiap keluarga, maka salah satu kebutuhan lingkungan untuk pemenuhan kebutuhan oksigen, dapat difasilitasi dan dipenuhi bersama. Dari hasil penelitian tergambarkan pada area yang 
memiliki ruang terbuka hijau dapat memberikan kenyamanan $100 \%$ kepada seluruh penghuninya, karena mampu mempertahankan suhu lingkungan berada di kisaran $21^{\circ} \mathrm{C}$ sampai dengan $24^{\circ} \mathrm{C}$, sehingga kelembaban relative terjaga dan tingkat radiasi pada area tersebut menurun (Sunaryo, 2015).

Untuk pemenuhan kebutuhan oksigen, setiap keluarga harus memperhatikan lingkungan sekitar rumah seperti ketersediaan alat bantu yang digunakan, dan apakah ada rumah yang digunakan untuk keperluan industri. Kondisi ini akan menambah kebutuhan oksigen yang diperlukan. Diperkirakan setiap orang membutuhkan oksigen perhari sebesar $840 \mathrm{gr}$, mobil pribadi 11.634gr, motor 582gr, truk 29760gr, bus 45760gr (Riyan, 2019). Hal lain yang harus diperhitungkan keluarga adalah faktor luar yang akan mempengaruhi tumbuhan seperti angin, suhu, kelembaban, intensitas matahari, dan faktor lainnya seperti jumlah penduduk dan hewan ternak (Afrizal, Fatimah \& Sulistyantara, 2010), termasuk ketersediaan air (Mulyati \& Mustika, 2019). Bila semua faktor tersebut diperhitungkan maka keluarga akan tahu berapa banyak pohon yang harus disediakan agar oksigen terpenuhi.

Setiap keluarga perlu mengenal jenis pohon dan kemanfaatannya serta cara bercocok tanam, agar dapat menentukan jenis tanaman apa yang perlu di sediakan di rumah tangga. Sebagai contoh praktis dapat diupayakan kegiatan pemanfaatan lahan pekarangan dengan melakukan penghijauan skala rumah tangga. Kegiatan ini sangat penting karena saat ini penelitian dan target penghijauan banyak dilakukan pada skala luas, sedangkan yang membahas pentingnya penyediaan oksigen di lingkungan rumah tangga masih sangat terbatas.

Berbagai kajian kebutuhan sudah banyak dibicarakan dan dihasilkan oleh para peneliti yang membuktikan bahwa pohon menjadi sumber utama penghasil oksigen dan menjadi jalan untuk mengatasi masalah polusi udara (Ardani, Hanafi, \& Pribadi, 2016 ;Silalahi \& Harianja, 2016; Zainudin, 2019; Sunaryo, 2015; Nowak, Hoehn, \& Crane, 2007; Mulyati \& Mustika, 2019; Afrizal, Fatimah \& Sulistyantara, 2010), kajian kebutuhan oksigen skala rumah tangga sangat dibutuhkan untuk mempercepat tujuan pemerintah pusat ataupun daerah dalam mengatasi polusi udara. Artikel ini bertujuan untuk memberikan gambaran kepada keluarga dalam memenuhi kebutuhan oksigen yang sangat diperlukan setiap mahluk hidup.

\section{MASALAH}

Tempat yang kami pilih adalah Komplek Bukit Indah Pasanggrahan, Blok I, Kel. Pasanggrahan, Kec. Ujung Berung, Kota Bandung. Alasan kami memilih tempat kegiatan tersebut adalah karena wilayah tersebut berada di wilayah perkotaan yang cukup minim area hijau. Selain itu, di wilayah tersebut, tingkat polusi udara sangatlah tinggi. 


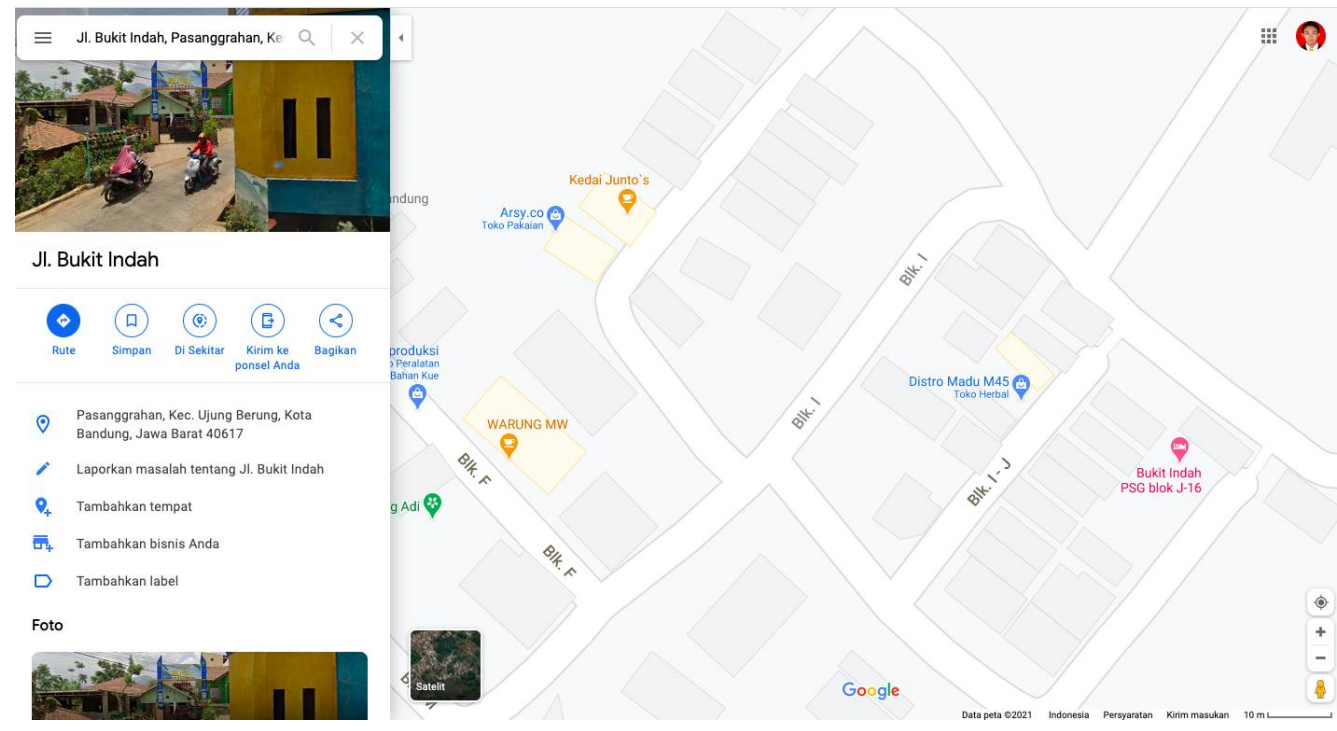

Gambar 1. Peta Lokasi Kegiatan Pengbdian Kepada Masyarakat.

\section{METODE}

Metode yang digunakan adalah deskriptif, berfokus pada penerapan suatu tindakan yang bertujuan untuk meningkatkan mutu lingkungan dalam menghasilkan oksigen yang menjadi kebutuhan utama setiap mahluk hidup yang diterapkan pada skala rumah tangga.

\section{HASIL DAN PEMBAHASAN}

Kegiatan penghijauan lingkungan rumah tangga dan pemanfaatan area pekarangan perlu dilakukan oleh keluarga sebagai upaya menghasilkan oksigen yang diperlukan. Penanaman bisa dikerjakan di berbagai area, seperti yang terlihat pada gambar berikut: 

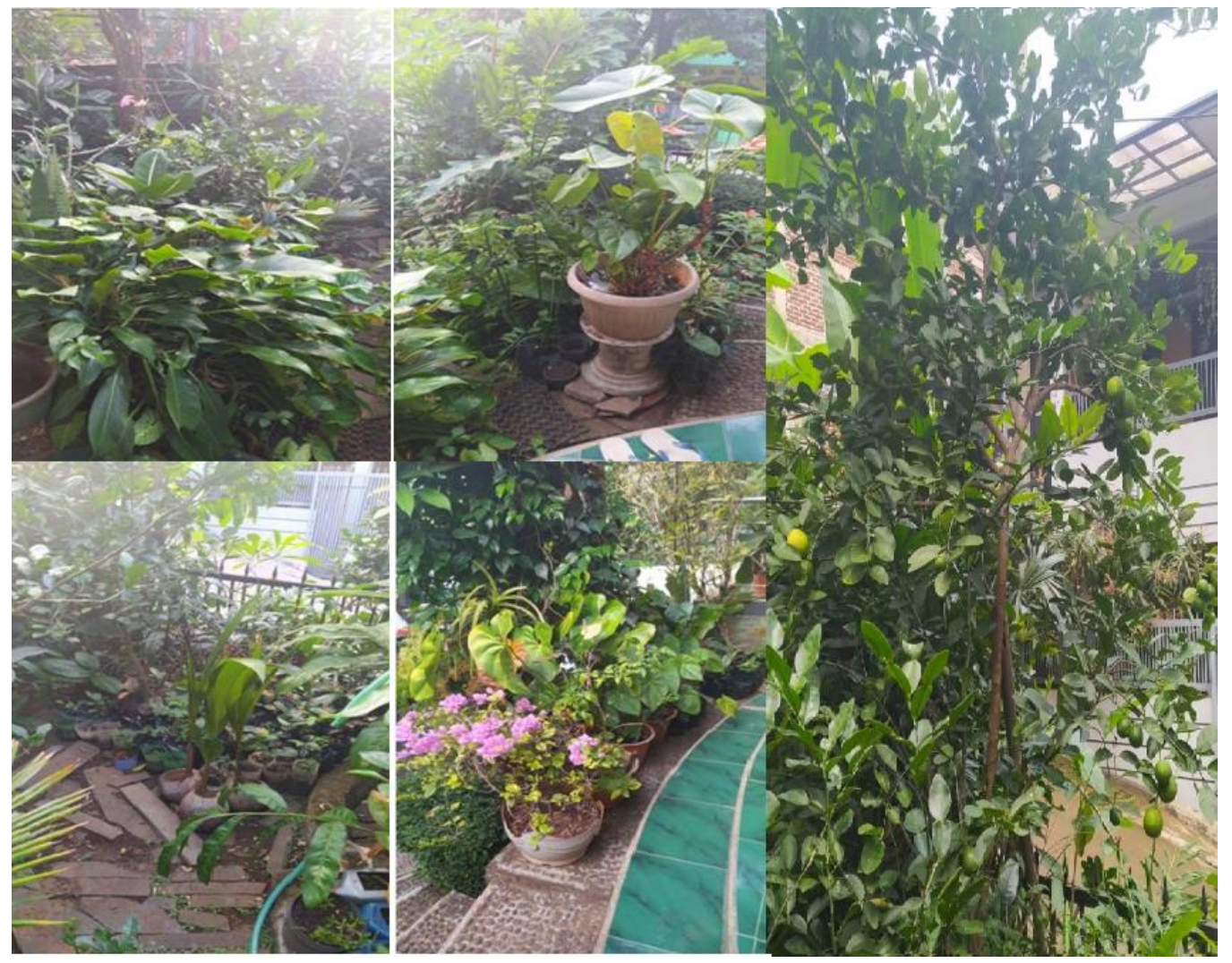

Gambar 2. Penanaman di area depan rumah

Pada area depan bisa ditanam berbagai macam tanaman hias dan produktif yang dapat bermanfaat bagi keluarga. Pada area samping dan pinggir jalan bisa dimanfaatkan untuk menanam berbagai jenis tanaman sayuran dan obat seperti jambu batu, sirih, sirsak, kunyit, jahe merah, laja merah, binahong, kelor, bidara, mahkota dewa, sereh, asam yang sudah banyak terbukti membantu penyembuhan berbagai macam penyakit. Sepanjang pinggir jalan ditanam pohon lidah mertua, kelor dan pohon pelindung agar produksi oksigen banyak dan mampu membantu menyerap timbal. Agar penanaman terus berlanjut diperlukan juga area pembibitan untuk menyemai berbagai tanaman produkktif yang bisa dikonsumsi harian untuk memenuhi kebutuhan keluarga. Tempat yang digunakan dalam penyemaian bisa menggunakan plastik bekas botol/ kresek bekas, sehingga akan mengurangi limbah plastik. Untuk tanaman lebih besar bisa menggunakan tas plastik bekas seperti yang tergambarkan pada gambar berikut. 


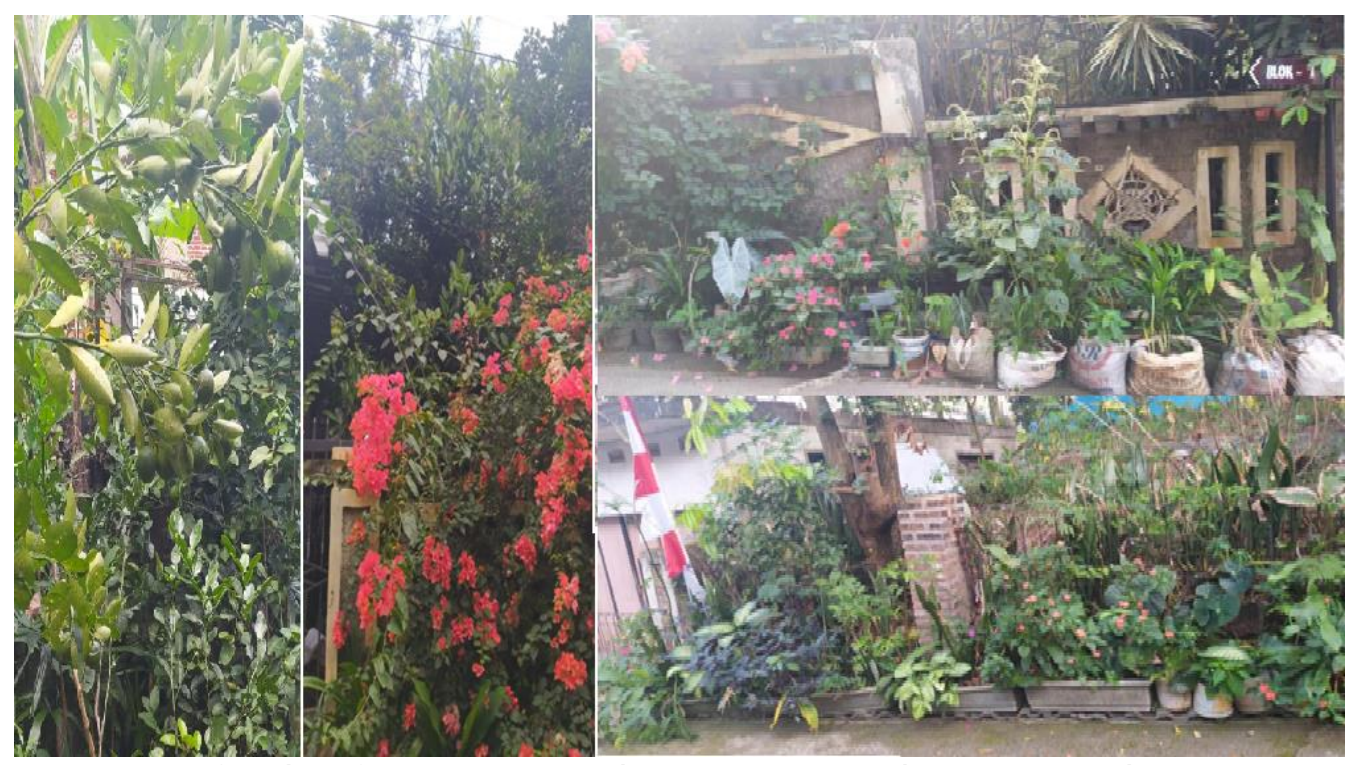

Gambar 3. Penanaman di area samping dan pinggir jalan

Pada area tanah bisa di tanam jenis pohon yang lebih besar dan produktif seperti pohon buah mangga, jeruk, jambu batu, jambu air, rambutan, pisang, sawo, pete, alpukat, nangka dll, disesuaikan dengan lahan yang tersedia. Bila area terbatas bisa menggunakan pot besar, karung, ember atau kaleng bekas. Banyak tanaman tentunya akan banyak sampah daun yang bisa dimanfaatkan untuk pembuatan kompos yang bisa menyuburkan tanaman.

Penanaman berbagai macam jenis pohon di tempat terbuka dan pemilihan tanaman akan membantu dalam memenuhi kebutuhan oksigen per rumah tangga, menambah kesejukan, kelembaban, kenyamanan lingkungan. Oksigen dapat dihasilkan banyak, CO2, dan timbal (Pb) dapar dinetralisir, air hujan dapat diserap tanaman, kondisi tanah akan semakin kuat.

Berdasarkan hasil wawancara dengan setiap orang yang berkunjung, mereka merasakan suhu di sekitar lingkungan rumah terasa dingin dan mereka merasa nyaman walaupun saat terik matahari. Udara di sekitar rumah terasa segar sepanjang hari, dan memberikan kenyamanan pandangan mata dengan tampilan daun yang hijau, bunga yang mekar serta buah buahan yang dihasilkan pohon. Beberapa tanaman sayuran dapat dihasilkan dari kegiatan ini, menjadi nilai tambah untuk kebutuhan keluarga.

Kondisi ini terjadi karena setiap pohon mempunyai kemampuan fotosintesis untuk menghasilkan oksigen dan menyerap karbondioksida. Hasil penelitian menjelaskan bahwa oksigen bisa di produksi oleh pohon besar, pohon agak tinggi dan tanaman rendah selama 11 jam/hari (06.00-17.00WIB) adalah $1.458,6 \mathrm{~kg} /$ hari (Mulyati \& Mustika, 2019). Bila kita menanam tanaman lainnya seperti tanaman puring (Codiaeum variegatum) atau lidah mertua (Sansevieria trispasciata), maka oksigen dapat dihasilkan sepanjang waktu, dan sekaligus mampu menyerap timbal akibat emisi kendaraan (Dewi \& Indri, 2012). Berdasarkan uraian tersebut bisa tergambarkan satu pohon besar hanya mampu memenuhi kebutuhan oksigen untuk 1-2 orang saja, dan pemilihan jenis tanaman akan ikut mempengaruhi kualitas udara.

Bila dalam satu keluarga ada 3 orang dan mempunyai kendaraan motor atau mobil maka kebutuhan oksigen yang diperlukan adalah $3 \times 840 \mathrm{gr}+11.634$ $\mathrm{gr}+582 \mathrm{gr}=3.113 .634 \mathrm{gr}$. Jadi untuk keluarga tersebut harus tersedia pohon besar 2 pohon ditambah pohon kecil lainnya atau 3 pohon besar. 
Jenis pohon besar yang disarankan ditanam di perumahan adalah pohon mangga. Tanaman ini bisa cepat tumbuh, berdaun lebat, berbuah, akar menembus ke dalam tanah, tidak merusak lantai dan tembok. Pohon ini umumnya mempunyai tinggi 4-10 meter. Tanaman lain yang bisa dipilih adalah pohon talok sebagai peneduh jalan, rambutan dan jambu air (Hutagalung; Delvian; Elfiati, 2016).

Perbaikan lingkungan untuk mengatasi polusi udara akan cepat teratasi bila seluruh keluarga yang ada dalam satu wilayah dilibatkan bersama. Kegiatan penghijauan yang berhasil membuat lingkungan lebih nyaman walaupun kondisi padat dilakukan di kelurahan Serengan Kota Surakarta. Semua masyarakat dilibatkan dalam proses perencanaan, penyediaan, pemeliharaan, serta pengawasan kegiatan penghijauan. Dalam kegiatan tersebut tergambarkan kondisi ekologi membaik, lingkungan menjadi indah, dan setiap keluarga mampu menanam tanaman yang menambah nilai ekonomi bagi keluarga (Rubiantoro \& Haryanto, 2013).

Jenis tanaman lain yang dapat dipilih dan mempunyai manfaat banyak adalah lidah mertua. Tanaman ini mempunyai keunggulan yang banyak, selain penghasil oksigen setiap waktu, tanaman ini juga dapat dimanfaatkan untuk obat. Senyawa saponin pada daun tersebut terbukti dapat menghambat produksi jaringan bekas luka yang berlebihan perhitungan kadar rata- rata saponin sebesar 3, 1258\% (Mien et al., 2015). Senyawa lainnya yang terkandung dalam daun ini adalah etanol. Zat ini terbukti dapat bekerja sebagai antimikroba pertumbuhan bakteri E. coli dan Streptococcus sp, makin tinggi konsentrasi ekstrak daun lidah mertua, makin luas zona jernih pada media kultur bakteri E. coli dan Streptococcus sp (Lombogia, Budiarso, \& Bodhi, 2016). Zat lainnya yang terkandung didalamnya adalah senyawa polifenol, flavonoid dan saponin yang merupakan agen antibakteri dan terbukti mampu menurunan jumlah kuman sebesar 52\% (Nurwaini \& Saputri, 2018). Hasil penelitian tersebut menunjukkan manfaat daun yang bisa digunakan keluarga untuk tujuan pengobatan.

Keunggulan lain yang bisa dimanfaatkan keluarga dari tanaman lidah mertua adalah bisa membantu menyerap timbal $(\mathrm{Pb})$ dari udara sekitar yang dihasilkan oleh emisi kendaraan bermotor. Daun ini mampu menyerap timbal rata rata perjam sebanyak $0,079 \mathrm{mg} / \mathrm{Kg}$ dan pohon lainnya yang lebih baik penyerapannya adalah puring. Pohon ini mampu menyerap rata-rata 0,64 $\mathrm{mg} / \mathrm{Kg}$ (Dewi \& Indri, 2012). Hasil penelitian ini bisa digunakan oleh keluarga sebagai bahan pertimbangan pemilihan jenis pohon dan tempat area tanamnya.

Selain itu, jenis tanaman lain yang dapat dipilih adalah pegagan (centella asiatica). Pegagan adalah ramuan obat penting yang banyak digunakan di Timur dan menjadi populer di Barat. Triterpenoid, saponin, unsur utama dari Pegagan diyakini bermanfaat dalam memberikan efek terapeutiknya yang luas. Selain penyembuhan luka, ramuan ini direkomendasikan untuk pengobatan berbagai kondisi kulit seperti kusta, lupus, bisul varises, eksim, psoriasis, diare, demam, amenore, penyakit saluran genitourinari wanita, mengatasi gangguan pencernaan dan juga untuk menghilangkan kecemasan dan meningkatkan kognisi (Gohil, Patel, \& Gajjar, 2010; Fadilah, Mardianingrum \& Agustien, 2020).

Perlu adanya pelatihan terhadap keluarga tentang pengolahan tanaman obat. Fadilah dan tim peneliti/pengabdian kepada masyarakat tahun 2020 melakukan pelatihan pengolahan pegagan terhadap masyarakat Desa Pagersari, Kabupaten Tasikmalaya. Hasil penelitian tersebut menunjukan 
bahwa pelatihan tersebut terbukti efektif dalam meningkatkan pengetahuan, sikap dan keterampilan masyarakat dalam mengolah pegagan sehingga dapat menjadi produk kesehatan (Fadilah, Mardianingrum \& Agustien, 2020).

Bila keluarga menginginkan ada manfaat lainnya dari penghijauan, keluarga dapat menanam tanaman produktif yang bernilai ekonomis seperti sayuran. Untuk tujuan ini, diperlukan pendampingan dan evaluasi agar pemahaman dan keterampilan bercocok tanam sayuran dikuasai oleh masyarakat (Ariyanto \& Saijo, 2018). Kegiatan ini akan memandirikan masyarakat dalam memenuhi kebutuhan sayuran.

\section{KESIMPULAN}

Pemanfaatan area pekarangan bisa membantu pemerintah dalam pemenuhan kebutuhan area hijau terbuka, untuk menghasilkan oksigen yang diperlukan oleh rumah tangga. Pemanfaatan area pekarangan ini dilakukan melalui penanaman berbagai jenis tanaman besar dan kecil disesuaikan dengan kondisi lingkungan serta tempat yang ada, dengan memanfaatkan limbah plastik, kaleng, karung, sebagai tempat bercocok tanam.

Banyak manfaat yang bisa didapatkan dari tanaman bila kita mengetahui zat yang terkandung didalamnya. Tanaman bisa dimanfaatkan sebagai obat herbal, dapat digunakan juga sebagai alat untuk mengatasi polusi udara akibat emisi kendaraan bermotor.

\section{DAFTAR PUSTAKA}

Afrizal, E.I., Fatimah, I.S., Sulistyantara, B. (2010). Studi Potensi Produksi Oksigen Hutan Kota Di Kampus Universitas Indonesia, Depok. Jurnal Lanskap Indonesia, 2(1), 23-29. https://doi.org/10.29244/jli.2010.2.1.\%p

Ardani, C., Hanafi, N., \& Pribadi, T. (2016). Perkiraan Luas Ruang Terbuika Hijau untuk Memenuhi Kebutuhan Oksigen di Kota Palangkaraya. Jurnal Hutan Tropis, 1(1), 32-38. https://doi.org/10.20527/JHT.V1I1.1481

Ariyanto, D., \& Saijo, S. (2018). Peningkatan Peran serta Masyarakat dalam Pemanfaatan Lahan Pekarangan melalui Penanaman Pohon Ekonomis di Desa Ciherang, Bogor, Jawa Barat. Jurnal Ilmiah Pengabdian Kepada Masyarakat, 3(2), 141-145. https://doi.org/10.33084/pengabdianmu.v3i2.381

Balan, P.T. (2019). Tingkat Pengetahuan Masyarakat Tentang Dampak Polusi Udara Pada Kesehatan. Skripsi. Universitas Sumatera Utara. Medan.

Budiyono, A. (2010). Pencemaran Udara: Dampak Pencemaran Udara Pada Lingkungan. Dirgantara, 2(1), 21-27.

Dewi, Y. S., \& Indri, H. (2012). Kajian Efektivitas Daun Puring (Codiaeum variegatum) dan Lidah Mertua (Sansevieria trifasciata) dalam menyerap Timbal di udara ambeien. Satya Negara Indonesia, Vol. 5, pp. 1-7.

Fadilah, N.N., Mardianingrum, R., Agustien, G.S. (2020). Pelatihan Pembuatan Serbuk Jamu Pegagan Di Desa Pagersari, Kecamatan Pagerageung, Kabupaten Tasikmalaya. Jurnal Kreativitas Pegabdian Kepada Masyarakat (PKM), 3(2), 501-507. https://doi.org/10.33024/jkpm.v3i2.3354

Gohil, K. J., Patel, J. A., \& Gajjar, A. K. (2010). Pharmacological Review on Centella asiatica: A Potential Herbal Cure-all. Indian journal of pharmaceutical sciences, 72(5), 546-556. https://doi.org/10.4103/0250- 
474X.78519

Gubernur JABAR. (2015). PERDA Provinsi Jawa Barat Nomor 5 Tahun 2015 (p. 31). p. 31.

Hutagalung, A.N., Delvian, D., Elfiati, D. (2016). Analisis Kualitas Pohon di 5 Jalur Hijau Kota Pematangsiantar ( Tree Quality Analysis on Five Green Belt in Pematangsiantar ). Peronema Forestry Science, 1-9.

Karyadi, H. (2005). Oxygen production by urban trees in the United States. Pengukuran Daya Serap Karbondioksida Lima Jenis Tanaman Hutan Kota, 33(3), 220-226.

Lombogia, B., Budiarso, F., \& Bodhi, W. (2016). Uji daya hambat ekstrak daun lidah mertua (Sansevieriae trifasciata folium) terhadap pertumbuhan bakteri Escherichia coli dan Streptococcus sp. Jurnal E-Biomedik, 4(1). https: / / doi.org/10.35790/ebm.4.1.2016.12230

Manisalidis, I., Stavropoulou, E., Stavropoulos, A., \& Bezirtzoglou, E. (2020). Environmental and Health Impacts of Air Pollution: A Review. Frontiers in public health, 8, 14. https://doi.org/10.3389/fpubh.2020.00014

Mien, D. J., Carolin, W. A., \& Firhani, P. A. (2015). Penetapan Kadar Saponin pada Ekstrak Daun Lidah Mertua (Sansevieria trifasciata Prain varietas S. Laurentii) Secara Gravimetri. Jurnal Ilmu Dan Teknologi Kesehatan, 2(2), 67.

Mulyati, M., \& Mustika, S. W. A. (2019). Kajian Kebutuhan Oksigen Terhadap Ruang Terbuka Hijau Kampus Bangau Universitas Katolik Musi Charitas Palembang. Sebatik, 23(2), 408-413. https: //doi.org/10.46984/sebatik.v23i2.791

Nurwaini, S., \& Saputri, I. D. (2018). Pengujian Sifat Fisik dan Aktivitas Antibakteri Sediaan Gel Hand Sanitizer Ekstrak Daun Lidah Mertua (Sansevieria trifasciata Prain). Talenta Conference Series: Tropical Medicine (TM), 1(3), 078-085. https://doi.org/10.32734/tm.v1i3.266

Pemerintah RI. (2014). Peraturan Pemerintah RI No 66 tentang Kesehatan Lingkungan (pp. 1-27). pp. 1-27.

Prabaningtyas, D. S., \& Priyo, E. (2020). Penebangan Pohon Dalam Pembangunan Jalan. 12(1), 93-98.

Riyan, Z. (2019). Analisis Ketersediaan Ruang Terbuka Hijau Perkotaan Muara Enim Berdasarkan Kebutuhan Oksigen. JJurnal Swarnabhumi, 4(1), 5160. https://doi.org/10.1017/CBO9781107415324.004

Rubiantoro, E. A., \& Haryanto, R. (2013). Bentuk Keterlibatan Masyarakat dalam Upaya Penghijauan pada Kawasan Hunian Padat di Kelurahan Serengan - Kota Surakarta. Jurnal Pembangunan Wilayah \& Kota, 9(4), 416. https: //doi.org/10.14710/pwk.v9i4.6679

Silalahi, J., \& Harianja, A. (2016). Analisis Kebutuhan Ruang Terbuka Hijau Publik Di Kota Bitung. Jurnal Berkala Ilmiah Efisiensi, 16(4).

Sunaryo, D. (2015). Studi Hubungan Ruang Terbuka Hijau, Temperatur Lingkungan Perkotaan dan Kebutuhan Konsumsi Oksigen Dengan Sistem Informasi Geografis. Spectra, 988-999. 